Przegląd Badań Edukacyjnych Educational Studies Review

ISSN $1895-4308$

nr 23 (2/2016), s. 85-104

ORYGINALNE ARTYKUŁY BADAWCZE

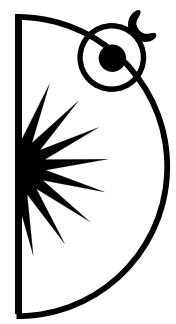

Natalia Walter

Uniwersytet im. Adama Mickiewicza, e-mail: Natalia.Walter@amu.edu.pl

\title{
Medialny wizerunek dzieci w spektrum zaburzeń autystycznych (ASD) kreowany przez rodziców blogerów
}

http://dx.doi.org/10.12775/PBE.2016.074

\section{Media Image of Children with Autistic Spectrum Disorders (ASD) Created by Their Blogging Parents}

\begin{abstract}
The paper discusses how children with some autistic spectrum disorders (ASD) are portrayed by their parents. In the first part we present autism and Asperger syndrome as medical cases, provide the definitions, characteristics and methods of therapy. Next, we analyze the media images of people with disabilities, including the stereotypic features emphasized in the media. Finally, we present the results of the study. The primary research problem refers to the question: What is the image of children with ASD that is created by the posts and memories on blogs written by their parents? The research is mostly qualitative. We applied an analysis of existing documents (internet diaries), which belong to a wider category of network ethnography (netnography). The analysis was conducted on 15 blogs. The results reveal that the actual image of a child with ASD is significantly different from a stereotypic images presented in the media. Blogs written by parents do not follow the stereotypes, and they rather focus on distinctive features and autonomy of the child. They mostly portray the children in context of hurdling various impediments and succeeding in small and larger matters, or outline their personal features and uniqueness. Therapies and treatments are considered as a means for realizing the dreams and plans of the child. Sometimes, autism is set in the background, as a part of everyday reality, which is not the object of the blog, but merely an intrinsic part of life. Children with ASD are usually portrayed in line with
\end{abstract}


the common, scientifically documented features specific for similar disorders. Blogging parents appear to have considerable knowledge on ASD and describe their children from that perspective.

Keywords: autism, parenting weblogs, media representation of disability

Zagadnieniem, któremu poświęam niniejszy artykuł są wybrane zaburzenia mieszczące się w spektrum autyzmu (Autism Spectrum Disorders - ASD). Opublikowane w 2013 r. piąte wydanie podręcznika Amerykańskiego Towarzystwa Psychiatrycznego: „Diagnostic and Statistical Manual of Mental Disorders" (DSM-V, 2013) spektrum autyzmu definiuje jako zaburzenia neurorozwojowe, objawiające się we wczesnym dzieciństwie lub obserwowane później. Zaburzenia te dotyczą dwóch sfer (w odróżnieniu od poprzednich wersji DSM, gdzie wymieniano trzy sfery): społeczno-komunikacyjnej oraz behawioralnej, obejmującej ograniczone, powtarzające się wzorce zachowań, zainteresowań i aktywności. Spektrum autyzmu w DSM-5 obejmuje takie zaburzenia, jak: autyzm, zespół Aspergera, dziecięce zaburzenia dezintegracyjne (czasem określane jako zespół Hellera) oraz zaburzenia neurorozwojowe nie zdiagnozowane inaczej (PDD NOS) (Lauritsen, 2013; DSM-5, 2013).

Od 1943 r., kiedy to po raz pierwszy L. Kanner scharakteryzował autyzm (kwestia ta poruszana jest w dalszej części artykułu), wielokrotnie zmieniało się jego ujmowanie na tle innych zaburzeń (por. Pisula, 2000; Kruk-Lasocka, 1998). Zmiany te najwyraźniej zauważalne są w dwóch największych systemach klasyfikacyjnych: w Międzynarodowej Klasyfikacji Chorób (International Classification of Diseases: ICD) Światowej Organizacji Zdrowia (World Health Organization: WHO) oraz Diagnostyczno-Statystycznym Podręczniku Zaburzeń Psychicznych (Diagnostic and Statistical Manual of Mental Disorders: DSM) Amerykańskiego Towarzystwa Psychiatrycznego (American Psychiatric Association: APA). W ICD-8 z roku 1967 autyzm był klasyfikowany jako nietypowa forma schizofrenii (pod uwagę był brany wtedy tylko autyzm wczesnodziecięcy). W DSM-III z 1980 r. zotał wprowadzony termin głębokiego zaburzenia rozwoju, a tym samym autyzm przestał być traktowany jako psychoza. Zespół Aspergera został włączony do ICD-10 w 1990 r. Pojawił się tam jako podgrupa całościowych zaburzeń rozwojowych (Wing, 2005). W DSM-IV pod pojęciem głębokiego zaburzenia rozwoju rozumie się grupę znacznych i rozległych zaburzeń, które zaczynają się ujawniać we wczesnym okresie życia dziecka i charakteryzują się zaburzeniami w trzech obszarach: 
socjalizacji, komunikacji, stereotypowych i perseweracyjnych zachowaniach (Pisula, 2000; Randall, Parker, 2001; Wing 2005). Z takich okresleń wycofano się w DSM-V.

\section{Kryteria diagnozy według DSM-5 i ICD-10}

By mówić o zaburzeniach mieszczących się w spektrum autyzmu, należy przeanalizować je pod kątem cech i objawów, które się ujawniają. W DSM-V wyróżnia się zatem cztery kryteria diagnozy (wszystkie muszą wystąpić): 1) Stałe deficyty w zakresie komunikacji społecznej i społecznej interakcji w różnych kontekstach, niewyjaśnione przez ogólne opóźnienia rozwojowe i manifestujące się przez: deficyty w zakresie społeczno-emocjonalnej wzajemności, deficyty w zakresie komunikacji niewerbalnej stosowanej w interakcjach społecznych, deficyty $\mathrm{w}$ zakresie rozwijania i podtrzymywania relacji, odpowiednio do poziomu rozwojowego (oprócz tych związanych z opiekunami; 2) Ograniczone, powtarzalne wzorce zachowania, zainteresowań lub aktywności, manifestujące się przynajmniej przez dwa spośród wymienionych: stereotypowa lub powtarzalna mowa, ruchy lub posługiwanie się przedmiotami (jak proste stereotypie ruchowe, echolalia, powtarzalne używanie przedmiotów itp.), nadmierne podporządkowanie rutynie, zrytualizowane wzorce zachowań werbalnych lub niewerbalnych, a także nadmierny opór wobec zmian, wysoce ograniczone, uporczywe zainteresowania, anormalne pod względem intensywności lub przedmiotu uwagi, hiper-lub hipo-reaktywność na sensoryczny wkład lub niezwykłe zainteresowanie sensorycznymi aspektami otoczenia; 3) Symptomy muszą być obecne we wczesnym dzieciństwie (ale mogą się nie manifestować do czasu, aż nie ujawią ich określone oczekiwania społeczne); 4) Wszystkie te symptomy ograniczają i upośledzają codzienne funkcjonowanie (DSM-V, 2013).

Zaburzenia $\mathrm{w}$ spektrum autyzmu pojawiają się również w klasyfikacji ICD-10, gdzie określane są mianem całościowych zaburzeń rozwojowych (F84), w których mieści się autyzm dziecięcy, autyzm atypowy, zespół Retta ${ }^{1}$, zespół Aspergera, zaburzenia hiperkinetyczne z towarzyszącym upośledze-

${ }^{1}$ Zespół Retta (RTT) jest neurorozwojowym schorzeniem uwarunkowanym genetycznie, które charakteryzuje się współwystępowaniem szeregu objawów klinicznych, głównie ze strony układu nerwowego, układu pokarmowego i kostnego. Zaburzenia powstają jako wynik mutacji określonego genu położonego w chromosomie żeńskim X. W zespole Retta wyróżnia się 4 fazy rozwojowe: 1) okres noworodkowy i wczesnodziecięcy, który jest prawidłowy; 2) faza szybkiego regresu, podczas której następuje utrata nabytych umiejętności komunikacyjnych i poznawczych, napady drgawkowe, stereotypie rąk, zaburzenia oddychania; 3) faza pseudostacjonarna 
niem umysłowym i ruchami stereotypowymi oraz inne całościowe zaburzenia rozwojowe oraz dziecięce zaburzenia dezintegracyjne. Należy podkreślić, że w DSM-V zrezygnowano z określenia „całościowe zaburzenie rozwoju”, a także wykluczono ze spektrum autyzmu zespół Retta oraz dziecięcych zaburzeń dezintegracyjnych. Wprowadzono natomiast trójstopniową klasyfikację ASD: od L1 do L3, w zależności od nasilenia objawów oraz stopnia ich oddziaływania na codzienne funkcjonowanie.

\section{Charakterystyka autyzmu}

Niniejszy artykuł będzie skoncentrowany szczególnie wokół dwóch rodzajów zaburzeń neurorozwojowych: autyzmu dziecięcego oraz zespołu Aspergera jako występujących najczęściej i mieszczących się w zakresie badań, które zostały omówione w dalszej części. Autyzm, opisany po raz pierwszy w 1943 r. przez Leo Kannera, to zaburzenie rozwoju, które ujawnia się w dwóch sferach wyróżnionych w DSM-V: społeczno-komunikacyjnej oraz behawioralnej. U osób z autyzmem zauważa się nieprawidłowości w przebiegu interakcji społecznych, ograniczenia w zakresie komunikowania oraz ograniczone, powtarzane wzorce aktywności, zachowań oraz zainteresowań (Pisula, 2000; Bowler, 2007). Pierwsze symptomy widoczne są zazwyczaj przed ukończeniem 36. miesiąca życia, a kolejne dołączają z czasem. Najczęściej występującym zaburzeniem tego typu jest autyzm wczesnodziecięcy, określany jako „zespół poważnych zaburzeń rozwojowych dziecka, manifestujących się do 30. miesiąca życia, związanych z wrodzonymi dysfunkcjami układu nerwowego" (Kruk-Lasocka, 1997, s. 246). W funkcjonowaniu społecznym ujawnia się niewystarczająca świadomość dotycząca egzystencji lub uczuć innych, trudności w odnalezieniu komfortu w czasie złego samopoczucia, trudności w nawiązywaniu relacji, rozumieniu konwencji zabaw i relacji. Bardzo charakterystyczne są deficyty komunikacyjne w zakresie mowy werbalnej i niewerbalnej, głównie w obrębie mimiki czy gestykulacji. Kolejną kwestią jest ograniczony repertuar aktywności, sztywność zachowania, powtarzanie wzorców. Typowe są tu manieryzmy ruchowe, stereotypie, sztywne przestrzeganie rytuałów i rutyn, ograniczony charakter zainteresowań (Pisula, 2000; Kruk-Lasocka, 1997). „Jako całościowe

(wiek przedszkolny i szkolny) i 4) faza stabilizacji. W zależności od mutacji genu MECP2 odpowiedzialnego za obecność zespołu Retta fenotyp dziewczynek jest zróżnicowany (Midro, 2010; Kosno, 2013). 
zaburzenie rozwoju, autyzm ma wpływ na wszystkie obszary funkcjonowania dziecka. Powoduje zaburzenia relacji społecznych i kontaktu, trudności z podporządkowaniem się regułom społecznym wynikające z braku ich zrozumienia. Większość dzieci autystycznych jest niemówiąca, nie komunikuje się gestem, ma trudności ze wskazywaniem, naśladowaniem, spełnianiem poleceń. Jeśli dzieci mówią, to są to często echolalie. Nie potrafią one tworzyć dłuższych rozbudowanych wypowiedzi, mają trudności z inicjowaniem i podtrzymywaniem wymiany konwersacyjnej. Cechuje je brak lub ograniczenie rozumienia pojęć abstrakcyjnych. Nawet dobrze funkcjonujący autyści mają problemy z pragmatyką języka. Dodatkowo obserwuje się u nich zaburzenia zachowania - liczne stereotypie i rytuały, koncentrowanie się na niefunkcjonalnych właściwościach przedmiotów, skrajne formy zaburzeń koncentracji. U niektórych pojawiają się także zachowania agresywne i autoagresywne" (Fundacja Synapsis, 2016). Należy również pamiętać, że ,autyzm stanowi zaburzenie rozwojowe i dlatego jego manifestacja $\mathrm{w}$ zachowaniu zmienia się wraz z wiekiem i zdolnościami. Jego główną cechą, obecną w różnej postaci we wszystkich stadiach rozwoju i przy wszystkich poziomach zdolności, stanowi upośledzenie socjalizacji, komunikacji i wyobraźni” (Frith, 2005, s. 8).

\section{Zespół Aspergera}

W spektrum autyzmu mieści się również zespół Aspergera, który został po raz pierwszy zdiagnozowany przez wiedeńskiego pediatrę Hansa Aspergera w 1944 r. Zaobserwował on powtarzające się charakterystyczne wzorce zachowań oraz możliwości, które ujawniały się u niektórych chłopców. Wzorce te obejmowały brak empatii, ograniczone zdolności nawiązywania przyjaźni, jednostronną komunikację, zaabsorbowanie określonymi zainteresowaniami oraz stereotypie ruchowe. W 1983 r. Lorna Wing uzupełniła te objawy jeszcze o pedantyzm oraz ograniczoną umiejętność komunikacji niewerbalnej (Attwood, 1998). Najłatwiej dostrzegalna różnica między osobami zmagającymi się z autyzmem (np. Kannera) a zespołem Aspergera dotyczy mowy. Dzieci z zespołem Aspergera zaczynają mówić w wieku około 2 lat (pierwsze słowa). Później ich słownik staje się bogaty, składnia jest poprawna, treść wyrażana metaforycznie, pojawiają się neologizmy (Pisula, 2000; Kruk-Lasocka, 1997). Dzieci z zespołem Aspergera bywają bardzo kreatywne, choć wiele z nich charakteryzuje pewna sztywność i schematyczność myślenia. Wielu autorów uważa, że zespół Aspergera jest rodzajem autyzmu, a mianem tym określa osoby wyżej funkcjonujące. 


\section{Potencjał intelektualny oraz etiologia osób z zaburzeniami w spektrumautyzmu}

W przypadku autyzmu dziecięcego ujawnia się niepełnosprawność intelektualna, która dotyka, według różnych źródeł, od 66 do 75\% populacji. Obniżenie zdolności intelektualnych dotyczy zwłaszcza sfery komunikacyjnej - dzieci ze spektrum autyzmu osiągały słabsze wyniki na przykład w testach werbalnych. U niektórych można zaobserwować z kolei tzw. zdolności wysepkowe (występują u około 5-15\% populacji): muzyczne, językowe, pamięciowe, percepcyjne, arytmetyczne, plastyczne (Pisula, 2000). „Jeśli chodzi o związek z upośledzeniem umysłowym, wiele badań wykazało, że kliniczny autyzm dziecięcy oraz podobne do niego zaburzenia mogą występować przy każdym poziomie inteligencji mierzonej standardowymi testami, chociaż większość osób jest upośledzona umysłowo, z czego ponad połowa mieści się w zakresie ciężkiego upośledzenia" (Wing, 2005, s. 133-134). Natomiast dzieci z zespołem Aspergera „wykonują testy inteligencji według typowego wzorca, ale w odróżnieniu od innych osób z autyzmem ich inteligencja mieści się zazwyczaj w normie" (Frith, 2005, s. 10-11). Co jest szczególnie istotne to fakt, że zespoły Kannera i Aspergera mieszczą się w obrębie kontinuum upośledzenia społecznego, ale cechuje je odrębny profil funkcji poznawczych, językowych i motorycznych (Wing, 2005).

Jeśli chodzi o etiologię zaburzeń autystycznych, wiąże się ona z szeregiem niepotwierdzonych hipotez. Nie udało się wyodrębnić jednego konkretnego czynnika, który byłby odpowiedzialny za wystąpienie autyzmu lub zespołu Aspergera. Badacze nie dostrzegli związku między ewentualnymi problemami w okresie ciąży i porodu a wystąpieniem zaburzeń autystycznych. Coraz liczniejsze badania wskazują na czynnik genetyczny jako najbardziej prawdopodobną przyczynę, przy czym obserwuje się bardzo złożony obraz, który najprawdopodobniej jest wynikiem wielu różnych czynników patogennych. Podejrzewa się również, że wpływ na ujawnienie się zaburzeń autystycznych mają czynniki neurologiczne i neurochemiczne, choć ich mechanizm również nie jest do końca zbadany (Pisula, 2000).

\section{Charakterystyka i wspieranie rozwoju dzieci z zaburzeniami w spektrum autyzmu}

Autyzm oraz zespół Aspergera są zaburzeniami rozwoju, zatem związane $\mathrm{z}$ nimi nieprawidłowości ujawniają się $\mathrm{w}$ różnych okresach życia dziecka. 
W przypadku autyzmu, w okresie niemowlęctwa i wczesnego dzieciństwa dostrzec można pierwsze zmiany w zachowaniu. Niektóre można zaobserwować przed pierwszymi urodzinami (w przypadku autyzmu wczesnodziecięcego) lub nieco później (odmiana późna). Wśród deficytów ujawniających się u małych dzieci wyróżnić można: rzadkie próby nawiązania kontaktu, rzadkie współdzielenie uwagi, rzadkie dzielenie pozytywnych emocji, sztywność w zabawie, ograniczony kontakt wzrokowy. W okresie przedszkolnym objawy się zazwyczaj nasilają - wtedy też najczęściej dochodzi do diagnozy. „Między 3. a 5. rokiem życia izolacja dziecka autystycznego jest szczególnie widoczna, stając się głównym źródłem stresu rodzicielskiego. $<<$ Ono jest najszczęśliwsze kiedy jest samo $>>,<<$ on zawsze patrzy przez ludzi $>>,<<$ ona nigdy nawet nie zerknęła na swoją nowonarodzoną siostrę >>, są to typowe spostrzeżenia rodziców" (Bobkowicz-Lewartowska, 2014, s. 60). Dzieci są słabo zainteresowane rówieśnikami, nie potrafią bawić się spontanicznie, bywają hiperaktywne. Te problemy silnie uwidaczniają się w szkole, gdzie trudności komunikacyjne i nienawiązywanie relacji wyraźnie odróżniają dzieci autystyczne od pozostałych. Jest to jednak także okres intensywnego rozwoju, gdyż opieka staje się wówczas profesjonalna (Pisula, 2000).

Wspieranie rozwoju dzieci z autyzmem polega na stosowaniu rozmaitych rodzajów terapii i rehabilitacji, dostosowanych do konkretnych trudności i deficytów. „Celem terapii dziecka z autyzmem jest sprawienie, by bliskość ludzi stała się dla niego ważniejsza niż przedmioty techniczne. W dzieciach tych trwa bowiem wciąż, wbrew pozorom, potrzeba tworzenia więzi z ludźmi oraz gotowość do jej nawiązywania" (Olechnowicz, Wiktorowicz, 2012, s. 11). Wśród najczęściej stosowanych znajdują się metody behawioralne, które choć skuteczne, budzą wiele kontrowersji. Ich celem jest zmiana zachowania dziecka: zwiększenie deficytowych zachowań, redukowanie zachowań niepożądanych, generalizowanie i utrzymywanie efektów terapii (Bobkowicz-Lewartowska, 2014). Ponadto stosuje się terapię psychologiczną oraz neurobiologiczną, w której wyróżnić można terapię słuchową, terapię funkcji wzrokowych, odbioru i przetwarzania bodźców węchowych, smakowych i dotykowych, stymulację rozwoju zabawy, stymulację funkcji lewej półkuli mózgu, terapię zachowań społecznych, stymulację funkcji motorycznych, kształtowanie systemu językowego oraz ćwiczenia pamięci (Cieszyńska, 2011). Z powodzeniem stosowany jest także kompleksowy program TEACCH (Treatment and Education of Autistic and Related Communication Handicapped Children). Wśród zasad programu wymienić można: polepszanie możliwości adaptacyjnych, uznanie rodziców jako współterapeutów, oszacowanie w celu ustalenia programu indywidualnej 
terapii, struktury nauczania, zastosowanie terapii behawioralnej i percepcyjnej, uniwersalny model szkolenia oraz podnoszenie umiejętności (Bobkowicz-Lewartowska, 2014). Brak jednorodnych symptomów zaburzeń spektrum autyzmu powoduje, że terapia musi być dobierana indywidualnie. Każde dziecko wymaga jej odmiennego rodzaju, tak by była ona skierowana na niwelowanie określonego deficytu lub deficytów. Problem stanowią licznie pojawiające się terapie, których skuteczność oceniana jest bardzo nisko lub też takie, których konsekwencją może być nawet pogorszenie stanu funkcjonalnego dziecka. Za przykład może tu posłużyć szeroko promowany trening integracji słuchowej, którego stosowanie, co prawda nie jest szkodliwe, ale jak pokazują badania, nie powoduje żadnych zmian we wrażliwości słuchowej dziecka (Pisula, 2012).

W przypadku osób z zespołem Aspergera również konieczne są oddziaływania terapeutyczne i wspieranie rozwoju. Jak twierdzi U. Frith (2005), osoby te „mogą nauczyć się rutynowych zachowań społecznych tak dobrze, że w opinii innych ludzi będą one uchodzić jedynie za ekscentryków". U dzieci $\mathrm{z}$ zespołem Aspergera stosuje się terapie podobne jak w autyzmie, tj. metoda behawioralna czy TEACCH. Ponadto można wskazać tu trening umiejętności społecznych (TUS), trening zastępowania agresji (TZA), Indywidualną Stymulację Słuchu Johansena (JIAS), Metody Stymulowanych Seryjnych Powtórzeń Ćwiczeń (SSP), The Son-Rise Program B. i S. Kaufmanów (metoda opcji), dogoterapię, hipoterapię, arteterapię, muzykoterapię oraz wiele innych, również takich, co do skuteczności których pojawiają się zasadne wątpliwości, jak trening słuchowy Tomatisa czy integracja sensoryczna SI (Całek, Łuszczak, Jankowska, 2014; Błaszczyński, 2013; Preißmann, 2013).

We wszystkich zaburzeniach spektrum autyzmu stosuje się program terapeutyczny stymulujący rozwój teorii umysłu i jest metodą pomocy w zakresie doskonalenia społecznych i komunikacyjnych umiejętności. Program obejmuje zadania dotyczące trzech obszarów funkcjonowania: emocji (rozwijanie rozumienia emocji innych ludzi), stanów wiedzy (przyjmowanie perspektywy innej osoby), zabawy w udawanie (zadania stymulujące rozwój umiejętności zabawy) (Howlin, Baron-Cohen, Hadwin, 2010).

\section{Media jako narzędzia kreowania wizerunku}

Media najczęściej definiowane są jako narzędzia, przedmioty i urządzenia przekazujące komunikaty od nadawcy do odbiorcy za pomocą słów, obrazów i dźwięków (tj. radio, telewizja, książka, prasa). Dodatkową ich zaletą jest umożliwienie użytkownikowi wykonywania czynności intelektualnych i manu- 
alnych (Strykowski, 1997). Rozwój technologiczny doprowadził do ekspansji mediów: ich wszechobecności, masowości i ogólnej dostępności. Stały się one zasadniczym narzędziem informacyjnym i komunikacyjnym, kształtującym poglądy i przekonania. W przypadku osób dorosłych stanowią podstawowe narzędzie edukacyjne. Media, jak pisał W. Okoń (2003), ułatwiają poznawanie rzeczywistości, zdobywanie wiedzy o rzeczywistości, kształtują emocjonalny stosunek odbiorców do niej oraz tę rzeczywistość przekształcają.

Ostatnie lata pokazują także, że stopniowo użytkownicy mediów przestają być bierni i czynnie angażują się w tworzenie komunikatów. Odbiorcy stają się prosumentami. „Zamiast mówić o pełniących osobne role producentach i konsu-mentach mediów, możemy dziś raczej postrzegać jednych i drugich jako uczestników wchodzących ze sobą w interakcje zgodnie $\mathrm{z}$ nowym zestawem regul, których nikt z nas w pełni nie rozumie. [...] Konsumpcja stała się procesem kolektywnym" (Jenkins, 2007, s. 9-10). Dzięki interaktywności, która jest zasadniczą cechą tzw. nowych mediów czy inaczej - multimediów, każdy może współtworzyć przestrzeń medialną, zyskując tym samym szansę na pokazanie siebie i przedstawienie wybranego aspektu rzeczywistości. Z możliwości tej korzysta wielu internautów.

Zarówno media tradycyjne (podające), jak i nowe (interaktywne) służą kreowaniu wizerunku osób, instytucji czy miejsc. Dla wielu grup społecznych stanowią jedyne źródło informacji na konkretny temat. A zatem pokazany przez nie wizerunek będzie dla wielu osób bazą, na której opierać będą postrzeganie i rozu-mienie określonych zjawisk społecznych. „Wedle jednej z najbardziej popularnych metafor media masowe są oknem na świat, przez które nie wychodząc z domu możemy oglądać, co się dzieje na zewnątrz naszego domu, miasta, kraju, kontynentu. Jednak to, co widzimy, to nie sama rzeczywistość, tylko jakieś jej odbicie, dlatego inna, nie mniej popularna metafora głosi, iż media to zwierciadło rzeczywistości” (Mrozowski, 2001).

\section{Medialna reprezentacja osób z niepełnosprawnością}

Osoby niepełnosprawne niezbyt często stają się bohaterami komunikatów medialnych. Gdy natomiast już to nastąpi, ujawniają się określone stereotypy. Według P. Hunta (1991) wyróżnić można 10 ich przejawów: osoby niepełnosprawne przedstawiane są jako godne pożałowania i żałosne, obiekty przemocy i zaciekawienia, groźne lub złe, superbohaterowie, jako osobliwość lub atmosfera, śmieszne, swoi najwięksi wrogowie, będący ciężarem dla innych, aseksualni. Pierwszy z wymienionych stereotypów jest najczęstszy - osoby niepełno- 
sprawne przedstawiane są jako walczące z trudnościami i będące przedmiotem uprzedzeń. Taka reprezentacja pojawia się w medialnych apelach o wsparcie charytatywne oraz w serialach telewizyjnych. Często też media pokazują wyłącznie niepełnosprawność, która jest łatwo dostrzegalna, budzi zainteresowanie, dziwi, a nawet szokuje. Wówczas osoby z niepełnosprawnością przedstawiane są w opozycji do pełnosprawnych. Tzw. „superkaleki” to kolejny chętnie powielany stereotyp. Tu akcentuje się osoby, które mimo niepełnosprawności osiągają sukcesy w różnych dziedzinach, np. w sporcie. Podobnie jak Hunt, wizerunki medialne przedstawił C. Barnes (1997): ludzie z niepełnosprawnością jako godni pożałowania, dotknięci przemocą, przerażający i źli, dziwolągi i osobliwości, superbohaterzy, obiekty drwin, wrodzy samym sobie, ciężar dla społeczeństwa, nienormalni seksualnie, niezdolni do pełnego udziału w życiu społecznym, a wreszcie, ale i najrzadziej: jako normalni ludzie.

Wizerunek medialny zyskały także osoby zmagające się z zaburzeniami w spektrum autyzmu. Przedstawiane są one najczęściej w dwóch ujęciach jako „zwariowani” sawanci (,nienormalni geniusze”) lub jako osoby niczym nie wyróżniające się ze społeczeństwa, w którym „każdy jest autystyczny” (Draaisma, 2009). Osoby ze spektrum autyzmu postrzegane bywają przez pryzmat takich filmów, jak „Rain Man” czy „Temple Grandin”, w których podkreślone są wybitne i rzadko spotykane zdolności bohaterów. $Z$ jednej strony takie pokazanie autyzmu skutkuje pozytywnym odbiorem i nastawieniem społecznym, z drugiej - powoduje błędne wnioski i interpretacje.

\section{Blogi rodzicielskie jako przestrzeń kreowania wizerunku dzieci z zaburzeniami w spektrum autyzmu}

Rozwój Internetu, zwłaszcza od momentu wynalezienia technologii Ajax i ukształtowania się przestrzeni tzw. Web 2.0, umożliwił internautom aktywny udział w tworzeniu zawartości sieci. Nieposiadający zaawansowanych umiejętności w zakresie konstruowania stron internetowych użytkownicy zyskali proste narzędzie komunikowania oraz publikowania treści. Dzięki tej funkcjonalności powstały i rozwinęły się takie usługi, jak: portale społecznościowe, wiki czy blogi. Te ostatnie pełnią funkcje pamiętnikarskie, jak i publicystyczne. Dotyczą różnych spraw, od politycznych poprzez hobbystyczne, zdrowotne, edukacyjne, jak i społeczne. Wielu rodziców dzieci z niepełnosprawnościami zdecydowało się na prowadzenie bloga. Przyczyny tego są wielorakie. $Z$ jednej strony blogi pełnią funkcję informatora o tym, co się dzieje $\mathrm{z}$ dzieckiem i całą rodziną, z drugiej - stanowią miejsce dzielenia się doświadczeniem, poszuki- 
wania i udzielania wsparcia oraz radzenia sobie w trudnej sytuacji, jaką jest niepełnosprawność dziecka.

Zdecydowałam się na przeprowadzenie badań, których celem było dokonanie analizy zawartości blogów prowadzonych przez rodziców dzieci z zaburzeniami w spektrum autyzmu oraz określenie ich znaczenia w kreowaniu wizerunku osób zmagających się z autyzmem. Zasadniczymi problemami badawczymi były pytania: Jaka jest przyczyna pisania blogów przez rodziców dzieci z zaburzeniami w spektrum autyzmu? Jaki wizerunek dzieci z zaburzeniami w spektrum autyzmu jest kreowany poprzez upublicznione wypowiedzi i wspomnienia rodziców? Badania miały charakter jakościowy. Zastosowaną metodą była analiza dokumentów zastanych, w tym przypadku - internetowych pamiętników, kóra wchodzi w zakres tzw. etnografii wirtualnej (netnografii) (Łuczewski, Bednarz-Łuczewska, 2012). Należy ją rozumieć jako „poznawanie i opisywanie ludzi oraz zjawisk na podstawie dających się zaobserwować w Internecie zachowań i ich efektów. Praca terenowa jest realizowana w zastanym środowisku internetowym w czasie rzeczywistym" (Cichocki, Jędrkiewicz, Zydel, 2012, s. 206). Etnografię wirtualną wykorzystuje się między innymi do „badania tożsamości, społeczności i relacji międzyludzkich, które powstają w Internecie" (Cichocki, Jędrkiewicz, Zydel, 2012, s. 208; por. Kozinets, 2012). Analizie poddano 15 blogów internetowych.

\section{Przyczyny prowadzenia blogów}

Wśród głównych przyczyn prowadzenia blogów można wyróżnić trzy zasadnicze. Po pierwsze, internetowe pamiętniki służyć mają uporządkowaniu myśli i poradzeniu sobie z emocjami rodziców, których dziecko zdiagnozowano jako znajdujące się w spektrum zaburzeń autystycznych. Po drugie, blogi z założenia stanowią przestrzeń dzielenia się posiadanymi informacjami na temat autyzmu, skutecznych terapii i metod wspomagania rozwoju. I, po trzecie, odgrywają rolę społeczną, stanowiąc swoistego rodzaju kampanie przybliżające różnym ludziom meandry życia rodziny z dzieckiem z autyzmem. Niezwykle trafnie określiła to jedna $\mathrm{z}$ mam-blogerek:

Postanowilam rozpoczać walkę z autyzmem. Jak to się w środowisku mówi Defeat Autism Now! - wszyscy w temacie wiedza o co chodzi. Będa frustracje, myśli nieokrzesane, załamania, upadki, wzloty. Mam nadzieję, że jak najwięcej tych ostatnich. Pragnę również podzielić się wiedza, która zgromadziłam, materiałami, doświadczeniem, które w miarę terapii będę zdobywać. Chcę pokazać co przeżywaja ro- 
dzice, a w szczególności ,,autystyczne matki”, stając codziennie na ringu, walczq starając się odpierać ciosy, godne niekiedy samego Tysona.

Chce pokazać jak ważne jest ciagłe uświadamianie, poglębianie wiedzy, szczególnie wśród lekarzy. Ciagle jeszcze zbyt mało dzieci jest zdiagnozowanych $w$ kierunku Autyzmu lub ASD, właśnie ze względu na brak podstawowej wiedzy lekarzy pierwszego kontaktu, którzy, nie boję się tego napisać - bagatelizuja problem. http://autystyczna-mama.bloog.pl/kat,0,m,8,page,5,r,2009,index.html, dostęp: 12.05.2016.

Wśród innych przyczyn wyróżnić można potrzebę poszukiwania wsparcia informacyjnego, materialnego czy emocjonalnego. Czasem autyzm nie jest też przedmiotem i głównym celem bloga, a jedynie elementem, który się pojawił częścią codzienności, która jest opisywana.

\section{Blog jako baza informacji na temat autyzmu}

W zasadzie wszystkie analizowane przeze mnie blogi zawierają charakterystykę zaburzeń rozwojowych w spektrum autyzmu. Niektóre z nich (np. http:// autystyczna-mama.bloog.pl) są prawdziwą kopalnią informacji na ten temat. Zawierają fragmenty artykułów, książek, stron internetowych. Odnoszą się do doniesień na temat skuteczności określonych terapii czy metod wspomagania rozwoju. Skrupulatnie analizują pojawiające się leki, diety, metody rehabilitacji oraz badania naukowe dotyczące autyzmu. Zawierają zarówno konkretne informacje, jak i linki do stron je zawierających. W wielu przypadkach odniesienia dotyczą najnowszych publikacji obcojęzycznych.

Blogerzy to także autorzy książek na temat autyzmu. Przykładem jest M. Klemczak, autorka bloga „Pamiętnik Babci Kubusia - AUTYZM” (http:// pokochajciekubusia.pl) oraz książki Autyzm, chaotyczny taniec umystu. Pamiętnik babci Kubusia (2012), o której sama pisze tak:

MOJA KSIĄŻKA... O KUBUSIU I DLA NIEGO. Nie, to nie jest dzieto. To prosty przekaz emocji jak trwać, konfrontując życie u boku dziecka z zaburzeniem. Skromny druk. Może tylko treść zaciekawi czytelnika. Treść, to spisanie myśli w formie pamiętnika. To KRZYK o tolerancję wobec INNOŚCI!!!

http://pokochajciekubusia.pl/?page_id=5009, dostęp: 12.05.2016.

Również blogerka, A. Kossowska (blog o Dzielnym Franku: http://dzielnyfranek.blogspot.com/) jest autorką książki Duże sprawy w małych głowach 
(2015), która „traktuje o różnych rodzajach niepełnosprawności. Celem jest opowiedzenie dzieciom, że niepełnosprawność to inne odczuwanie, widzenie, czasem także inne rozumienie świata" (https:/www.facebook.com/duze.sprawy /info/?tab=page_info, 2015). Jeden z rozdziałów tej niezwykłej publikacji poświę-cony został autyzmowi.

Nazywam się Franio. Mam 6 lat.

Nie mówię, ale wszystko potrafie powiedzieć rękami albo obrazkami. Te obrazki nazywaja się piktogramy.

Pani doktor mówi, że mam autyzm [...]

Nie lubię zmian i niespodzianek. Dlatego zawsze rano rodzice uktadaja mi plan dnia z piktogramów.

Gdy wygladam przez okno, widzę zawias w huśtawce, czerwone skarpetki chtopca, kwiatek na trawie. Mama mówi, że to dzieci bawia się na dworze, ale trudno mi zobaczyć to wszystko razem.

Moje oczy nie widza świata tak jak twoje.

Moja skóra nie czuje dotyku tak jak twoja.

Moje uszy nie stysza tak jak twoje. Czy wiesz, że sa dźwięki, których stuchanie mnie boli? Boję się dźwięku wiertarki, suszarki do rąk w toalecie i syreny strażackiej.

M. Kossowska (2015)

Blogujący rodzice, co jest warte zauważenia, zawsze odnoszą się głównie do własnych doświadczeń i to wielokrotnie podkreślają. Proszą czytelników o podchodzenie $\mathrm{z}$ dystansem do wszelkich wypowiedzi i postów, ponieważ nie mają one charakteru uniwersalnego i nie mogą stanowić punktu odniesienia. Natomiast chętnie odsyłają do sprawdzonych publikacji oraz stron internetowych. Informują o możliwościach dofinansowania oraz innych formach wsparcia. Publikują listy instytucji, których statutowym celem jest pomoc rodzinom dzieci z zaburzeniami rozwojowymi w spektrum autyzmu.

\section{Charakterystyka dzieci z zaburzeniami w spektrum autyzmu - wizerunek kreowany przez blogujących rodziców}

Jednym ze sposobów opisywania dzieci z zespołem zaburzeń autystycznych jest koncentrowanie się na tzw. małych i wielkich sukcesach, czyli na pokonywaniu trudności rozwojowych takich, jak: nauka picia, mówienia, adekwatnego reagowania na dźwięki, rozszerzanie diety przy nadwrażliwości w obrębie jamy ustnej i przełyku, sukcesach szkolnych i społecznych. 
P. ostatnio dużo się śmieje. Jest szkoła i nauczyciele, bus nadal przyjeżḋ̇a (uff! - ci sami ludzie, co wcześniej), jest terapia (środowiskowa, zatem systemowa :) Pani, która uczy mówić nadal to robi. Świat trwa! Pewnie P. cieszy się także dlatego, że powrócita jedna z jego „,bylych dziewczyn”, terapeutek, które pojawily się w naszym systemie. Jest tym wyraźnie przejęty, zadowolony i często chwali się swoimi pracami. Robi ich zreszta więcej niż rok temu i to jest odpowiedź naszego systemu na jego niepokój, braki w terapii SI.

http://autystyczni.blox.pl/html/1310721,262146,14,15.html?8,2014, dostęp:

12.05.2016.

W zasadzie żaden z blogów nie miał jednak charakteru wyłącznie optymistycznego. Bardzo często rodzice opisując swoje dzieci zwracają uwagę na pojawiające się regresy i nawarstwiające trudności w funkcjonowaniu.

Kto poskłada puzzle z rozbitego świata temu matemu chtopcu? Regres to takie stowo którym się straszy. A to nie o to chodzi. Strasznie jest patrzeć na mate ciatko wierzgające na podłodze w odruchu bezsilności. Na te wielkie oczy petne tez, gdy w nocy biega po mieszkaniu. Na małe nózki tupiące ze złościq i uciekające $z$ wózka na środku ulicy. Ja już byłam w tym miejscu. dawno temu. On też. Teraz musimy sprawić żeby wrócić do siebie. I ja i on. Stracit kontrole nad swoim matym światem i muszę się postarać żeby ja odzyskat. Stato się już i się nie odstanie, ale przerabianie od poczatku tego samego jest jak nie przymierzajac syzyfowa praca. 7 minut w playroomie. Ucieka. 10. ucieka. Wczoraj pót godziny. Ulga. Powoli. Krok po kroku. Skaczemy na materacu. Nosimy się. Skaczemy. Nosimy. Spacery nie wchodza w gre. Ucieka do każdej bramy. To też już było.

To co wypracowane kiedys wróci. Tak powiedziała nasza pani doktor. http://przebudzenieburaska.blox.pl/html/page/43.html, dostęp: 12.05.2016.

A zatem pierwszy wyłaniający się blogowy wizerunek jest następujący: dziecko z za-burzeniami autystycznymi charakteryzuje wiele niepokojących zachowań, pojawiających się trudności w codziennym funkcjonowaniu (zwłaszcza w dwóch sferach: społecznej i komunikacyjnej), które są stopniowo pokonywane. Wiąże się to z ogromnym wysiłkiem rodziców, terapeutów i nauczycieli. Wielokrotnie też zaobserwować można regres w zachowaniu i wypracowanych wcześniej postępach. Ogólnie jednak, zdaniem blogerów, dziecko „wychodzi z autyzmu”, „budzi się do normalnego świata”. Autyzm bywa traktowany zatem jako trudne, ale przejściowe zaburzenie, z którego można wyjść. 
[...] od 4 lat o tej samej porze dostaje jeść, ubiera te same rzeczy dzień po dniu, po płycie z piosenkami o skrzatach musi obejrzeć krecika, po kapaniu musi skakać 20 minut na łóżku i obiegać mieszkanie wokoło, nie założy nowych butów, nie akceptuje zmian środowiska, nie zje nowej potrawy mimo kamuflowania w tej której zna, nie wypije innego soku niż czerwony, nie wyjdzie z łazienki dopóki nie wyleję wody z miski...

http://przebudzenieburaska.blox.pl/html/page/43.html, dostęp: 12.05.2016.

Dziecko z zaburzeniami w spektrum autyzmu przedstawiane bywa przez rodziców nie tylko w kontekście trudności rozwojowych, ale też jako określona indywidualność, jednostka posiadająca swoje upodobania, plany, marzenia i uzdolnienia. Terapia traktowana jest wyłącznie jako sposób na ułatwienie realizacji zamierzeń i osiągnięcie szczęścia.

Nasza strategia nie jest walka z przeszkodami na terapeutycznej drodze. My nie uważamy, że King Konga trzeba leczyć, albo poprawiać. Akceptujemy go (majac na uwadze, że akceptacja to afirmacja piękna) takim jaki jest. Terapia ma jedynie na celu usunięcie tego co mu uniemożliwia odczuwanie radości. Nadwrażliwość na dźwięki przeszkadzała, to się nia zajęliśmy. I tak dalej. Długo by opowiadać. Ojciec nie uważa, że trzeba kogoś leczyć z tego jaki jest. Każdy jaki jest powinien mieć możliwość siebie rozwijania.

Tak w ogóle jest dobrze. King Kong zmierza w kierunku kolejnego wyróżnienia pod tytutem ,Wzorowy uczen'”, będzie reprezentowat szkołe w zawodach sportowych (musi sobie ojciec przypomnieć, żeby napisać mu pozwolenie ;)), sam się zapisat na jakiś konkurs uczniowski. Zuch, czy jakoś tak. Powiedziat, że chce zobaczyć jak to wyglada. I nie zależy mu na zwycięstwie. Powiedziat też, że mu nie zależy na odznace wzorowego ucznia. Że dla niego jest ważne, żeby nie być uczniem złym. Takim, który szkodzi. Fajnie nie?

http://ojcieckarmiacy.blox.pl/html/page/2.html, dostęp: 12.05.2016.

$\mathrm{Na}$ blogach pojawiają się zatem żartobliwe opisy zachowań i rozmów prowadzonych przez dzieci. Pokazują one autystyków w kontekście nie tylko zaburzeń rozwojowych, ale też osobniczych cech charakteru, przyzwyczajeń i talentów. To bardzo humanistyczny wizerunek dziecka, które mimo trudności wpisanych w zaburzenie rozwojowe, jest jedynym w swoim rodzaju człowiekiem, którym można się zachwycić. 
Wreszcie, autyzm w blogowych opowieściach staje się tłem, codziennością, czymś, do czego można przywyknąć i czymś, co nie determinuje wszystkich działań i aktywności rodziny.

Ja nie umiem pisać o autyzmie już. Tematycznie wygasło. On jest z nami, już zawsze będzie. Bez pytania i zgody staliśmy się para specjalna w objęciach potwora. Dobrze pamiętam ten czas, kiedy jedynym marzeniem (obojga? - nie mam pewności, nie pytałam) była myśl, by jutra nie było. Trzęsienie ziemi.

Ocaleli wszyscy.

Autyzm stat się powszedni. Ot, taka normalność. W niczym nie przeszkadza, wpisat się w każdy dzień, stat się niezauważalny.

Wtaściwie nawet nie ma o czym pisać.

http://cappuccino.blox.pl/html, dostęp: 12.05.2016.

Co bardzo ważne - w blogach nie istnieją stereotypy postrzegania niepeł-nosprawności. Ponieważ każdy z sieciowych pamiętników jest silnie zindywidualizowany, nie ma mowy o przeinaczeniach czy nadmiernym akcen-towaniu zewnętrznych przejawów autyzmu. Wszyscy autorzy blogów zachwycają ogromną wiedzą na temat zaburzeń rozwojowych i możliwych terapii. Nie ma tu powielania powszechnych niesprawdzonych opinii ani stereotypowego myślenia. Każda znaleziona w fachowej literaturze cecha czy właściwość jest szczegółowo analizowana i poparta konkretnymi przykładami zachowań. Wiele blogów zawiera też piękne fotografie, na których dzieci przedstawiane są w sposób akcentujący ich naturalne piękno i radość. Nie podkreśla się ani nie manifestuje niepełnosprawności, co nie znaczy, że się o niej nie opowiada, nierzadko przecież z troską i rezygnacją.

\section{Wnioski i podsumowanie}

Wizerunek dziecka z zaburzeniami rozwojowymi w spektrum autyzmu znacząco odbiega od stereotypowego przedstawiania takich osób w mediach. Filmy oraz telewizyjne komunikaty pokazują zazwyczaj specyficzny fragment życia oraz wybrane zachowania dzieci z ASD. Często akcentuje się w nich zdolności wysepkowe lub utożsamia autyzm z sawantyzmem, co jest niezgodne $\mathrm{z}$ rzeczywistością. Blogi pisane przez rodziców nie powielają takich stereotypów. Nie uwypuklają też trudów opieki nad dziećmi z niepełnosprawnością, co jest kolejnym stereotypem powszechnym w mediach tradycyjnych. Koncentrują się wokół specyfiki dziecka, z którym mają do czynienia na co dzień. Przedstawiają 
je albo w kontekście pokonywania trudności i osiągania drobnych i większych sukcesów, albo akcentują jego cechy osobowości i niepowtarzalność. Wówczas terapie traktowane są jako element niezbędny do tego, by marzenia i plany dziecka mogły zostać w przyszłości zrealizowane. Czasem autyzm stanowi element tła, codzienność, która nie jest sednem rozważań, a jedynie nieodłączną częścią funkcjonowania rodziny, do której można przywyknąć. Dzieci z ASD zazwyczaj pokazywane są zgodnie z powszechnie znanymi, udokumentowanymi naukowo cechami charakterystycznymi dla tego typu zaburzeń. Blogujący rodzice posiadają ogromną wiedzę z zakresu spektrum autyzmu i do niej odnoszą się opisując własne dziecko. A zatem blogowy portret dziecka z ASD nie ma nic wspólnego z superbohaterem ani z osobą godną pożałowania, nie jest groźny lub zły, nie jest śmieszny ani nie jest ciężarem dla innych. To po prostu upodmiotowione dziecko, które zmaga się z trudnościami rozwojowymi, wpływającymi na nie w większym lub mniejszym stopniu.

W trakcie mojej pracy zawodowej w szkole dla dzieci z niepełnosprawnością sprzężoną oraz wcześniejszego wolontariatu we Wspólnocie Burego Misia wielo-krotnie stykałam się z problemem zaburzeń rozwojowych w spektrum autyzmu. Z powodu niedostatku wiedzy praktycznej na ten temat, ogromnym wyzwaniem było dla mnie zazwyczaj nawiązanie, a potem podtrzymanie kontaktu oraz komunikacja. Trudnością był też brak kontaktu wzrokowego oraz brak empatii. Zawsze jednak w końcu zachwycałam się osobą, do której z takim trudem udawało mi się dotrzeć. We wspomnieniach wracam do chłopca, dla którego podstawą myślenia, zapamiętywania i wyrażania siebie były obrazy. Pamiętam też takiego, który marzył o tym, by jeździć czerwonym samochodem strażackim. Pamiętam jego zachowania autoagresywne i późniejszy trudny powrót do świata - tak odległego mimo fizycznej bliskości. Blogi pisane przez rodziców dzieci z zaburzeniami w spektrum autyzmu stanowią niezastąpione źródło informacji zarówno na temat samej niepełnosprawności, jak i funkcjonowania rodzin borykających się z nią. Dla pedagogów, którzy pracują lub planują pracę z osobami z zaburzeniami rozwojowymi, blogi parentingowe winny stać się lekturą obowiązkową.

\section{Bibliografia}

Attwood T. (1998), Asperger's Syndrome: A Guide for Parents and Professionals, Jessica Kingsley Publishers, London.

Barnes C. (1997), Wizerunki niepetnosprawności i media - badanie sposobów przedstawia- 
nia osób niepełnosprawnych w środkach przekazu, Ogólnopolski Sejmik Osób Niepełnosprawnych, Warszawa, s. 19.

Błaszczyński J. (red.) (2013), Terapie wspomagające rozwój osób z autyzmem, Oficyna Wydawnicza „Impuls”, Kraków.

Bobkowicz-Lewartowska L. (2014), Autyzm dziecięcy, Oficyna Wydawnicza IMPULS, Kraków.

Bowler D. (2007), Autism Spectrum Disorders. Psychological Theory and Research, John Wiley\&Sons, Ltd., Chichester, England.

Całek G., Łuszczak H., Jankowska H. (2014), Mam dziecko z zespołem Aspergera. Poradnik dla rodziców, Polskie Towrzystwo Zespołu Aspergera, Warszawa.

Cichocki P., Jędrkiewicz T., Zydel R. (2012), Etnografia wirtualna, w: Badania jakościowe. Metody i narzędzia, t. 2, D. Jemielniak (red.), Wydawnictwo Naukowe PWN, Warszawa, s. 203-219.

Cieszyńska J. (2011), Wczesna diagnoza i terapia zaburzeń autystycznych. Metoda krakowska, Omega Stage Systems, Kraków.

Diagnostic and Statistical Manual of Mental Disorders (DSM-V) (2013), Autism Spectrum Disorders, American Psychiatric Association, Washington.

Draaisma D. (2009), Stereotypes of autism, "Philosophical Transactions", 364(1522), pp. 1475-1480. DOI: 10.1098/rstb.2008.0324.

Frith U. (2005), Asperger i zespót Aspergera, w: Autyzm i zespót Aspergera, U. Frith (red.), Wydawnictwo Lekarskie PZWL, Warszawa, s. 4-45

Fundacja Synapsis (2016), Objawy autyzmu, http://synapsis.org.pl/autyzm/objawy, dostęp: 16.02.2016.

Howlin P., Baron-Cohen S., Hadwin J. (2000), Jak uczyć dzieci z autyzmem czytania umysłu, Wydawnictwo JAK, Kraków.

Hunt P. (1991), Discrimination: Disabled people and the media, "Contact", No. 70, pp. $45-48$.

ICD-10 (2016), International Classification of Diseases and Related Health Problems, World Health Organizations, Geneva, http://apps.who.int/classifications/icd10/browse/2016/en.

Jenkins H. (2007), Kultura konwergencji: Zderzenie starych i nowych mediów, Wydawnictwa Akademickie i Profesjonalne, Warszawa.

Kosno D. (2013), Zespót Retta - zaburzenia neurorozwojowe o podtożu genetycznym, w: Nieznane? Poznane. Zaburzenia rozwojowe u dzieci z rzadkimi zespołami genetycz- 
nymi i wadami wrodzonymi, M. Buchnat, K. Pawelczak (red.), Wydawnictwo Naukowe UAM, Poznań, ss. 157-176.

Kossowska A. (2015), Duże sprawy w małych głowach, Stowarzyszenie Terapeutów Zależnych, Opole.

Kozinets R.V. (2012), Netnografia. Badania etnograficzne online, Wydawnictwo Naukowe PWN, Warszawa.

Kruk-Lasocka J. (1998), Pedagogika dzieci z autyzmem i zespołami psychozopodobnymi, w: Pedagogika specjalna, W. Dykcik (red.), Wydawnictwo Naukowe UAM, Poznań, s. 245-257.

Lauritsen M.B. (2013), Autism spectrum disorders, "European Child \& Adolescent Psychiatry", February 2013, Volume 22, Supplement 1, pp. 37-42. DOI: 10.1007/s00787-0120359-5.

Łuczewski M., Bednarz-Łuczewska P. (2012), Analiza dokumentów zastanych, w: Badania jakościowe. Metody i narzędzia, D. Jemielniak (red.), t. 2, PWN, Warszawa, s. 163-185.

Midro A.T. (2010), Zespót Retta - postępy badań nad patogeneza, „Neurologia Dziecięca”, 19, 28; ss. 55-63.

Okoń W. (2003), Wprowadzenie do dydaktyki ogólnej, Wydawnictwo Akademickie „Żak”, Warszawa.

Olechnowicz H., Wiktorowicz R. (2012), Dziecko z autyzmem, Wydawnictwo Naukowe PWN, Warszawa.

Pisula E. (2000), Autyzm u dzieci. Diagnoza, klasyfikacja, etiologia, Wydawnictwo Naukowe PWN, Warszawa.

Pisula E. (2012), Autyzm. Od badań mózgu do praktyki psychologicznej, GWP, Sopot.

Preißmann Ch. (2013), Zespót Aspergera. Jak z nim żyć. Jak pomagać. Jak prowadzić terapię, Gdańskie Wydawnictwo Psychologiczne, Sopot.

Randall P., Parker J. (2001), Autyzm. Jak pomóc rodzinie, Gdańskie Wydawnictwo Psychologiczne, Gdańsk.

Strykowski W. (1997), Media w edukacji: od nowych technik nauczania do pedagogiki i edukacji medialnej, w: Media a edukacja, Strykowski W. (red.), eMPi2, Poznań, s. 11-20.

Wing L. (2005), Związek między zespołem Aspergera i autyzmem Kannera, w: Autyzm i zespót Aspergera, U. Frith (red.), Wydawnictwo Lekarskie PZWL, Warszawa, s. 115-149. 
